\title{
Johan Adam Möhler and N.F.S. Grundtvig: The Bridge of Romanticism
}

\author{
By R. William Franklin
}

Johann Adam Möhler (1796-1838) was one of the circle of young Roman Catholic theologians at the University of Tübingen in the southwestern German kingdom of Württemberg who provided a Christian response to modernization during the middle years of the age of revolution, 1825 to 1838 . Möhler was born into the patchwork of tiny German states stitched together between Bavaria in the east, Baden in the west, and the Rhineland in the north. He grew up amid the ruins of Roman Catholic institutions in Germany which were the result of Napoleon's Reichsdeputationshauptschluss of 1803, at a time when celibacy for the ordained, allegiance to the papacy, and the use of Latin were all being questioned by German Catholics.

Möhler himself was reported to have developed after his ordination to the priesthood a brief, platonic, but nevertheless passionate interest in a young Protestant woman, Emilie Siegel, from Stuttgart. At one point he was educated in Berlin under the shadow of a militaristic Prussia riding among the German states, and in 1835 Möhler was forced out of Tübingen by the Protestant king of Württemberg. Napoleon, Prussia, and the plight of Catholics in Württemberg set the context from which Möhler wrote two of the most influential works of nineteenth-century ecclesiology: Die Einheit, or The Unity in the Church, of 1825, and Symbolik, or The Symbolism, of 1832, 1825 and 1832 also two key dates in the life of N.F.S. Grundtvig.'

Not only the dates but also the themes of Möhler recall Grundtvig. To Möhler the essence of the church of 1825 was the entire people of God, not the hierarchy alone. The fundamental shift in his Catholic ecclesiology matched the radical change in Europe from monarchy to an era when »We the People« had become the motto of an age. In an age of revolution that witnessed not only the liberation of the people but also the threat of a new absolutism as represented by Napoleon, Prussia, or Württemberg, Möhler beheld Christianity not as the rules and dogma of hierarchy, but as a higher way of life made available to all people.

From this perspective it is possible to place Möhler in the nineteenth century pantheon alongside Daniel O'Connel or Abraham Lin- 
coln, as a theologcal emancipator of the Catholic laity, and yet it is also possible to define the Möhlerian project as a significant restatement of Catholic teaching on Tradition for the new condition of the nineteenth century. Möhler manufactured an ecclesiology that was an alloy, a dynamic evolving along a creative »middle way « that was at once conservative, in that it looked to the Tradition of the past defined as the institutional structures of the Christian faith that had grown up during the patristic centuries, as a standard for the contemporary church, and progressive, in that it sought to create a revived community life for the laity appropriate to modern conditions.

On the progressive side, because he believed that the celebration of Eucharist pointed to the essential communal nature of the church, Möhler issued a revolutionary call for a return to the earliest structures of Christian worship in which the assembly of the laity united in the closest possible manner with everyting that was said and done at the altar by the presider. At a time when Roman Catholic prelates were not disturbed that the laity had little idea of what was happening at a Mass, did not receive communion within the Mass, and did not join their voices to the priest during the Mass propers, Möhler campaigned against private Masses, he called for a return of the communion cup to the laity at Mass after a millenium of denial, and in the Tübingen Catholic journal Theoligische Qartalschrift he mocked the current arguments that the language of the liturgy should be Latin because of its antiquity and its ability to build up a world-wide human unity. »Such a Unity! « he wrote in 1825 , »a unity based on ignorance and as for antiquity, why not use Hebrew in the liturgy?... Let the people understand their prayers. $\ll^{2}$

On the conservative side, Möhler defended Catholic Tradition as the institutional arch upon which each Christian community must be constructed so that the koinonia of worship, participation and fellowship of all - particularly the laity, might be translated into the concrete realities of diakonia, Christian service that humanizes an increasingly fragmented modern society. Möhler's shift to a more conservative stance was a part of his response in the name of Christianity to what he feared to be the dangers of modernization. After 1830 Möhler's theology shifted to the right as it was shaped by new experiences which convinced him of the potentially dehumanizing aspect of the growing might of the state. From exile in Munich, after being removed from Tübingen by a Protestant king who wished to 
eliminate the possibility that the Catholic Church or Catholic professors might emerge as an independent political influence, Möhler closely followed developments to the north in Prussia: the imprisonment of a Rhineland archbishop and then a Polish archbishop because both refused to sanction government orders directed at their clergy. Within Württemberg and Prussia there were attempts to curtail the free use of the Roman liturgy and to adapt the Roman Rite to liturgical variations drawn up by the state. Behind these events Möhler saw already dawning upon humankind the figure of the totalitarian state. ${ }^{3}$

»If there will be no higher power than the state in Europe, then human freedom has come to an end, « Möhler wrote in $1837 .{ }^{4}$ Only in an international religious community with a marked transcendent dimension could a full humanism be guaranteed for nineteenthcentury Europeans to offset the divisive tendencies of nationalism. Like other Roman Catholics who turned to the right as the threats of nationalism loomed larger, for example Pius IX, Dom Guéranger, and Lacordaire, Möhler came to appreciate the papacy and celibacy as nurturing the transcendent and freedom-producing aspects of the church. Though he slowly embraced the papacy - which we could see as an institution set against human freedom in the nineteenth century - as a legitimate aspect of Catholic Tradition, Möhler never abandoned his understanding of Catholic Tradition, which was a new depar-ture. »Tradition, « in Möhler's definition, »is the expression through the centuries - at every moment living, and at the same time taking body - of the Holy Spirit who animates the totality of the faithful. «5

Such a definition of the church as corporate totality with mystical spirit, rather than as a legal entity in the manner of the seventeenthcentury theologist Robert Bellarmine who perceived the church as a militant perfect society of ordered ranks »like the Kingdom of France or the Republic of Venice, « is based by Möhler, as it was by Grundtvig, on the incarnation. ${ }^{6}$ From the perspective of the Vatican II era, the significant advance of Möhler's incarnational ecclesiology was that it bridged the post-Tridentine chasm between people and Tradition, as Grundtvig himself was able to do, fusing the two with Möhler's popularization of the term sensus fidelium and narrowing the distinctions for the future by reviving the Pauline and patristic metaphors of the church as »the body of Christ. «In the fifteenth century a book that had sought to revive Augustine's formulation of the 
church as »body of Christ « had been condemned by the Council of Basel as »offensive to pious ears. ${ }^{7}$

Now in Möhler the church, with its structured Tradition of primate, episcopate, presbyterate, and sensus fidelium, is a visible divinely constituted body which is the manifestation of Christ's saving mercy. The celebration of the Eucharist is the supreme action by which each Christian comes into his or her own as a member of Christ's body. This linking of Eucharistic fellowship to the concrete institutions of the church, Möhler's revival of the phrases »the Church as the mystical body of Christ " and sensus fidelium, as well as the merging of Tradition into »the flow from the same divine well-spring « as Scripture, each of these advances in ecclesiology came to stand behind the thinking of the German and French Roman Catholic theologians who fashioned a revised understanding of Catholic Tradition at Vatican Council II. ${ }^{8}$

Theologians who prepared the way for a change of thinking at the Second Vatican Council, from cardinal Ratzinger and Hans Küng to Yves Congar, who died recently, all would admit of some debt to Möhler. Congar wrote: »Thanks to Pierre Chenu, I was given the first idea, global in its implication, of Möhler... I felt that I had not only found a breach in the bastion of the post-Tridentine Church, but an inspiration, a source, a new synthesis. $"$ And George Tavard has defined Möhler's significance this way: »Modern Catholic ecclesiology...began to mushroom in the second half of the nineteenth century. The movement started in Germany where the school of Tübingen, notably with Johann Adam Möhler...saw the church primarily as a living organism led by the Spirit. ${ }^{10}$ The strength of Möhler's synthesis of people and Tradition was that it was grounded upon a return to the church of the first centuries, to the patristic era, as the model of a new Catholicism for the age of revolution.

II.

Can we think of Grundtvig as a contemporary northern parallel to Möhler within another great church? If we shift the prism of history and see the Copenhagen preacher and the Tübingen theologian as part of one common European cultural dynamic, we begin to see 
things that nineteen-century Roman Catholics and Lutherans had in common.

In his earliest years in Udby and in Jutland, Grundtvig had been of the opinion that the church's whole foundation was sola scriptura, the Bible and the Bible alone. But just a few years before the Catholic to the south, he arrived at a view similar to Möhler's view that it was the church itself, and its Tradition, especially as expresed in the Apostolic confession at baptism, that was the basis of the Christian faith. Christ was not to be sought in a book of the past, but in a living community of »the people «, engrafted by baptism, nourished by the Eurcharist. It is in the congregation, at baptism and communion, that Christ speaks his living Word to the community, or as Grundtvig put it himself: »No book can confer life, not even the Bible. The Christian community is no mere reading club; it is a fellowship of faith begotten and preserved through the spoken word as this goes down from generation to generation. ${ }^{11}$ The people, not the book, were the channel of revelation.

This view Grundtvig put before the public for the first time in a publication that appeared in 1825 - the annus mirabilis also of Möhler's Einheit. Grundtvig's book of 1825 was entitled Kirkens Gienmale: The Church's Retort. ${ }^{12}$ The reply Grundtvig made on the church's behalf was addressed to a professor of theology in Copenhagen, H.N. Clausen, who had brought out a book on the doctrine of Catholicism and Protestantism. For Clausen, the Bible was the undoubted foundation of Christianity, and the truth was to be deduced from it alone with the aid of reason. ${ }^{13}$ This view ran completely counter to Grundtvig's account of the Christian faith. He had become convinced that the church needs some authority which lies beyond question as the basis of sound spiritual life. His answer had come in what Grundtvig hereafter spoke of as his »matchless discovery, « which itself fell in this period of $1825-1826 .{ }^{14}$ The discovery was this: modern Christians in a sceptical age may appeal from the letter of scripture to not a dead but a »living Word, « the church's confession of faith as that has been handed down through the centuries by the human community renewed continuously in the waters of baptism. ${ }^{15}$

Möhler's central concept for 1825 was unity, and at the same moment in Kirkens Gienmale Grundtvig maintained that the essence of Christianity does not lie in any fixed text, but in a spiritual unity 
which has somehow been present in a variety of diverse human forms which Christianity has assumed in the course of the centuries, a unity that is so rich that it brings forth these forms, sometimes contradictory and in tension, out of its own fullness and still has more to be revealed. As with Möhler, the church for Grundtvig is at the mid-point of this evolving unity. Grundtvig shares with Möhler an identical sense of the one Church of Christ as one monumental, historic, organic reality. He means by this that the church is the place, not the state or the university or the corporation, where the whole of human life, the whole of human existence, finds its integrity and meaning. Grundtvig reminds, at times in violent language, that for a thousand years the life of the Danish people has been rooted in another and greater Tradition than the state, that of the universal Church of Christ. He sets so high a value on the church as bearer of salvation that he used language which clearly suggested a departure from the Protestant position, as when he translated the great battlehymn of the Reformation in a form which suggested that the church rather than God is the stronghold in which faith takes refuge. ${ }^{16}$ Yet there is a departure here in Denmark also: Grundtvig's is a "people's church, « not a church of the clergy. The community as such and not the ordained alone are the custodians of this Tradition, which is appealed to in 1825 precisely in order to dispense with the tutelage of the laity of the north to the priesthood and the professoriat. ${ }^{17}$

We see here that there are already four points of convergence of Grundtvig with Möhler by 1825 :

1. He is concerned to make a first-hand »traditional« religion possible for the common man and woman amid the revolutionary circumstances of the nineteenth century.

2. He wants to stress the universal elements of this Christianity as opposed to the denominational elements of it.

3. He wishes through worship to reinforce a sense of universal solidarity not only among the living but also with the dead.

4. This solidarity is sacramental: It is in the celebration of the sacraments and within the congregation at worship that we hear God's Word to us, God's creative Word, which brings into being the church, the new people of God. 
How far did Grundtvig accomplish his task? As an American surveying the Danish terrain from afar more than a century after his death, I can assert that he was as equally as influential within his national church over the long term as Möhler was in the Roman Catholic Church. Through the efforts in large part of Grundtvig in the nineteenth century, a sense of the church was successfully restored in Denmark before the disdainful frowns and sneers of liberal and secularist sceptics who looked upon churches and religion as more or less archaic hangovers from the past, destined, like warfare, to fade away in the light of reason and self-interest. By the end of his life the eucharist had become again the regular form of worship in the Danish church, celebrated twice every Sunday or festival in the town churches, and at »High Mass « in the country churches. In these circumstances God came to be grasped as a new source of energy for the time, and the Grundtvigians addressed God in new energetic forms - poems, folk-dances, and folk songs. Grundtvig successfully integrated the traditional products of the folk-life of the people into their worship through the use of weaving, carving, and carpentry to brighten the worship space and through songs and dance to bring joy to the church. And here is a Danish voice: »His influence can be detected to this day in almost every area of the national life and there are few persons in Denmark who are not to some extent affected by his work. ${ }^{18}$

III.

The coincidence of the appearance, of the survival, and eventually of the triumph of these two figures in Germany and Denmark, similar in the aspects of Christianity which they emphasized, demands a proper explanation today. Möhler and the Tübingen Catholic School, Grundtvig and the Grundtvigians, were each movements launched to restore a corporate conception of Christianity for the first generation of Europeans forced to confront a democratic, industrial, and predominantly secular civilization. For the first time since the Reformation era there was a rediscovery by a Roman Catholic and a Lutheran of prayer as a social act with humanistic implications. The similarities suggest that one distant but highly significant root of modern ecumenical convergence can be found in the parallel attempts one hundred 
and seventy years ago, in a variety of nations and denominations, to address Christianity to the newly-emerging forces of modernization, political land industrial revolution. ${ }^{19}$

From the perspective of secular history this rise of a new corporate Catholicism in southern Germany and the rise of a new corporate Lutheranism in Denmark is an important phenomenon because it forms part of a much larger search for community in the nineteenth century that took many forms and has many sources and lines of descent far transcending the Roman Catholic or even the Lutheran theological world. Grundtvig discovered a craving for human fellowship in many places he visited. His trips to England were later to be very significant in this regard. All over Europe men and women were longing to share a common life. He was sharply opposed to, and wanted to begin a reaction against, the dominant individualism of his time. In the 1832 introduction to a volume on Nordic mythology, he defined the fellowship needed in modern society as an aspect of »folk-life«. For Grundtvig, »folk-life« meant an existence that is not a matter of private concern alone; it is a corporate life that finds its earthly home in the created world. In addition, Grundtvig reminded his contemporaries of the historic tradition of eucharistic fellowship at worship that the Lutheran churches had largely abandoned. ${ }^{20}$

Similarly, in the first three centuries of Christianity, Möhler found a new definition of Catholicism for the nineteenth century: faith establishes a living, organic relationship with other human beings as well as with God, and the Mass establishes this bond of faith-fellowship. Humans are, in a deeply mysterious way, instruments of the salvation of which they are also the beneficiaries. Liturgical acts - the acts of worship during the Mass - are the chief signs of the human participation in the redemptive process. It is for these two reasons the celebration of Mass pointing to the communal nature of the church, active participation of the laity pointing to the corporate nature of the church - that Möhler encouraged all members of the community to perform their proper role in a church service. ${ }^{21}$

However, this recovery of the corporate dimension of existence can be found in many other areas of the nineteenth century, secular as well as religious. Community in economic relationships is a theme of Karl Marx, and the Modern Movement in architecture, from William Morris through the Bauhaus, sought to translate principles of Gothic communalism into a modern style appropriate for an industrial 
civilization. Richard Wagner envisioned that music-drama at Bayreuth would demonstrate organic unity in a fragmented German industrial society. It is not by accident that I have listed Marx, Wagner, and the Bauhaus - all significant German secular movements that would profoundly influence modern culture, for German secular thought, and above all Romanticism, was one common source of much that was revolutionary in Möhler's Catholic thought, and Romanticism was also one source, among many, of the new departures in Grundtvig. ${ }^{22}$

Northern German Protestantism, decisively shaped by Romanticism, nurtured Möhler's concept of community when the Tübingen Catholic faculty made the extraordinary gesture of sending the young priest north to Berlin for further study from the fall of 1822 to the spring of 1823. Möhler arrived in Berlin amid a great flowing of Protestantism characterized by Lord Acton as having $»$ no parallel in modern history except the revival of the fifteenth century. « ${ }^{23} \mathrm{~A}$ revival of the communal dimension of Christianity formed a part of this Protestant renaissance. Despite his epistemological subjectivism, Schleiermacher advocated in Berlin that the richest consciousness of God is prepared by fellowship with others. After 1813, Augustus Neander, a Schleiermacher disciple, had become the Berlin historian of the early Christian experience of community, and Neander set before Möhler the forgotten world of the patristic church: the fellowship, sharing, and corporate celebration the early church experienced in its liturgical worship; the essential vision of the patristic church as that of a community propagating itself in opposition to the dominant pagan power.

Möhler was equally influenced from 1824 by his felllow Swabian, the Lutheran Friedrich Schelling, and this led him further into German Romanticism. German Romanticism is an ill-defined period or movement with a mass of figures and interests. In contrast to the Enlightenment and its emphasis on analysis, edification, virtue, and rationality in Christian life, Romanticism strove for totality, organicism, and universalism. The intuitive contact by our consciousness with the absolute replaced the previous rational format of the Enlightenment. By the 1820's Schelling had announced his completion for the final, positive, concrete, and historical Christian system. It is a prototype of the great intellectual constructs which were a foundation for European culture after 1800. 
But already in $1800-1802$ in fact was the year Grundtvig was first introduced to Schelling - Schelling had revolutionized the Kantian shift in philosophy by complementing the transcendental philosophy of the world-creating self with the world of nature as analyzed by the new sciences of chemistry and electricity. ${ }^{24}$ Although for us Idealism is »romantic, « for Schelling it was »objective«: meaning positive, concrete, historical, and corporate. Schelling convinced Möhler that God's objective revelation was being carried forth in the history of the church, that the inner core of God's communication to humans was molded into ever-changing outer phenomena by the forces of secular history. Therefore it was from Schelling that Möhler learned that history and theology must be studied together, and the Romantic philosophy of Schelling was also a source of Möhler's discovery of the key role of »the people « in the church. The push for the enfranchisement of all classes and groups in Möhler flowed from Schelling's emphasis on the natural need for an organic dimension of life as an expansion of the life-feeling. ${ }^{25}$

Schelling turned to humankind as a whole rather than to individuals for an accounting of knowledge, morality, and art. The idea was developed in his system that the individual ego does not exist in isolation, but that it is a particular in a larger world soul which unites all being into one unity as a part of the larger divine oneness. The foundation of such a unity was the common people. The forms of art and life of ordinary folk were given new value in Schelling's system because they were said to reflect Gemeingeist, the spirit of a united humanity. Schelling became interested in the church because it appeared to be a historic unity, touching the mass of humanity, always expressing itself in new forms, yet forever maintaining its essential intellectual core unchanged. Geiselman, the principal historian of the Catholic Tübingen School, has summarized Schelling's impact on Möhler in this way: »The influence of the Romantic world showed him (Möhler) a deeper understanding of what a body is... The idea of community came in opposition to the (earlier) concentration on the single individual. ${ }^{26}$ In Die Einheit in der Kirche of 1825 we witness Möhler translating the Romantic concept of a people's community into an ecclesiology which associates »the people « once again with Tradition through the concept of sensus fidelium. It was Schelling who opened the door to this synthesis which would be so vital for the future of Roman Catholicism. ${ }^{27}$ 
IV.

How did Grundtvig arrive at his »matchless discovery - the Word first in corporate confession, sacrament, and worship and then the Bible? He has given us two answers. According to one, he reached the "matchless discovery « by a sudden inspiration which came to him as a result of prayer and the reading of Irenaeus. ${ }^{28}$ According to his second answer, it was the climax slowly reached of a train of thought and often painful personal experience in which Romanticism also played a part in leading him to the discovery of some authority which would be accessible to ordinary Christians without the mediation of professional scholars and theologians. ${ }^{29}$

This evolution began in 1802 when Grundtvig fell under the influence of the prolonged stay in Copenhagen of the Danish-NorwegianGerman philosopher and man of letters Henrik Steffens. Steffens's and Grundtvig's mothers were sisters, and the cousin older by ten years opened Grundtvig's eyes to European currents and literature from outside Denmark - Shakespeare, Goethe, and Cervantes. ${ }^{30}$ But above all in a lecture-room in Copenhagen crowded with eager young Danes Steffens presented ideas of Schelling that would prove so attractive to Grundtvig: the rejection of the mathematical explanation of nature which the eighteenth century had carried to triumph; by contrast Schelling's vision of nature as a pulsing, throbbing lifespirit; the infinite and finite as but differing aspects of the one worldhistory seen as the continuous self-expression of the Godhead in which each nation and each epoch has its place assigned to it; creation as a divine work which never ceases and in which all of humankind are called to be participants. Schelling provided a standpoint from which it was possible for Grundtvig to survey as a unity the various territories of human experience. ${ }^{31}$

What Grundtvig drew ultimately from Schelling over the course of the next two and one-half decades was the possibility of the complementarity of opposites - life and death, myth and Gospel, man and Christian. In this way Romanticism was a door which led to Grundtvig's expanded understanding of the doctrine of the Incarnation as the center around which everything else in Christianity should revolve in a century in which faith was faced with a fundamental crisis provoked by the historical criticism of scripture and the development of a scientific world-view in the public at large, both of which 
seemed to undercut foundations of theistic belief: the Incarnation not simply as a doctrine about the nature of Jesus Christ, but much more importantly as a way of understanding the relationship of the historic community of the church through the ages to the Word of God. Schelling beckoned Grundtvig back to older, pre-Enlightenment, ultimately by 1825 to a patristic way of thinking about the Incarnation: that human history and the created order as a whole can be the locus of divine presence, that God is present to humans not by negation but through a long process of perfecting and completing what humanity is. ${ }^{32}$ This patristic way of understanding the Incarnation with its emphasis upon the authority of the worshipping community as in some sense an extension of the Incarnation allowed Grundtvig to hold a particular balance, a particular tension, in which the authority of scripture could be recognized, but always as that was interpreted within the historical evolution and sacramental practice of the church. $^{33}$

V.

Seventy years ago Anton Mayer wrote a sixty-four page essay, »Liturgy, Romanticism and Restoration, « which begins by observing the vastness of the cultural world of Möhler and Grundtvig: »The river of Romanticism flows before our eyes without shore or end; the more one tries to recognize its essence, its direction, and its content within a thousand forms and phenomena, the more groundless and definitionless, the more confused and twisted is the picture. ${ }^{34}$ Mayer's essay is typical of the antiromantic mood prevalent earlier in this century. He sees chaos in the movement, ambiguity and irrationality in the impact of Romanticism on Christianity. The inner pattern of the period escapes him. ${ }^{35}$ Mayer is typical of Lutherans and Roman Catholics of the twentieth century who have denied or been ashamed of the influence of German Romanticism. Two world wars have not helped matters any. Yet to be understood in their fullness, Möhler and Grundtvig must be seen as part of an international cultural dynamic in which Romanticism played a role, in which Christianity, confronted by modernization turned back to themes of people and community which marked the pre-Constantinian era, a dynamic that owed much to the realization that, with the spread of mechanical 
power and the displacement of absolute monarchy, the social order that had been in existence for over a thousand years in Western civilization had come to an end.

It is as a part of this international response to modernization, that I as a foreigner to Denmark wish you to think about the legacy which Grundtvig left to his country. Grundtvig deserves also to be remembered as a prophet who could summon his people to such a love of country as would make them leaders in international cooperation. He showed that the new world of democracy and industry, social endeavor, national solidarity and human rights is not opposed to Christian internationalism, but can be enlisted in its service.

For Christians today international cooperation can not be isolated from ecumenism; there may be an ecumenical lesson to heed in this nineteenth-century material. From the perspective of the modern ecumenical movement, this point of contact between Lutherans and Roman Catholics one hundred and seventy years ago is an important phenomenon because it demonstrates the existence of a much more venerable dynamic toward reconciliation between Lutherans and Roman Catholics than many may have imagined, far transcending the immediate fortunes of twentieth century ecumenism. The forces of history, the chance encounter, the accidental friendship all play a role in this dynamic, along-side the official tetxts and congresses that constitute the history of the ecumenical movement. But amid all of this the constant factor has been the Christian individual willing to take a stand, who has seized the opportunity and marshalled the potential of each moment that has marked the stages of this advance. Though theologians of the first half of the nineteenth century served only remotely as a preparation for the modern ecumenical movement, they do mark the starting point that beckoned the churches forward toward a Christian consummatio which is part of God's plan for the fulfillment of humanity, destined for the future. Möhler and Grundtvig must be included in this company. ${ }^{36}$

\section{Notes}

1 Emilie Siegel was also a friend of the famous David Friedrich Strauss who discussed Möhler's attachment to Siegel in H.B. Oppenheim, Deutsche Jahrbücher für Politik und Literatur, Bd. 13 (1864) p. 385-92; and »Erinnerungen an Möhler, aufgezeichnet von einer Protestantin 1839«, Deutsche 
Jahrbücher für Politik und Literatur (1863) p. 8; and in D.F. Strauss, Kleine Schriften, II (Berlin: Weidmannsche Buchhandlung, 1866), p. 35280.

Möhler's works: Die Einheit in der Kirche, edited, with a commentary by Josef Rupert Geiselmann (Cologne: Jakob Henger 1957). Other editions of this in 1825, 1843, and 1925. Symbolik oder Darstellung der dogmatischen Gegensätze der Katholiken und Protestanten (Cologne: Jakob Hegner 1958). Thirteen editions of Symbolik have been published in Germany.

2 J.A. Möhler, »Rezension: F. Walter, Lehrbuch des Kirchenrechts, «Theologische Quartalschrift (hereafter cited as THQ) 5 (1823), p. 263-99; »Rezension: C.F.L. Schaaf, Die Kirchen-Agendensache, "THQ 7 (1825), p. $285-92$.

3 The three leading liturgical reformers of southwestern Germany during the late Enlightenment period, Maria von Werkmeister, Beda Pracher, and Ignaz Heinrich von Wessenberg, each looked upon the secular state as a force for the renewal of worship against the repressive hand of Rome. This terrain is discussed in Erwin Keller, »Die Konstanzer Liturgiereform unter Ignaz Heinrich von Wessenberg, "Freiburger Diözesan-Archiv 85 (1965), pp. $40 \mathrm{ff}$.

4 J.A. Möhler, »Über die neuste Bekämpfung der Katholischen Kirche, « Gesammelte Schriften, II, p. 229.

5 Einheit, p. 121. The most important work on Möhler and Tradition is Josef Rupert Geiselmann, Lebendiger Glaube aus geheiligter Überlieferung (Freiburg: Herder, 1966). The most important studies of the shift in Möhler's ecclesiology are also by Josef Rupert Geiselmann, Die theologische Anthropologie Johann Adam Möhlers (Freiburg: Herder: 1955), and »Johann Adam Möhler und die Entwicklung seines Kirchenbegriffs, «THQ 112 (1931), p.1-91.

6 Bellarmine in Peter Nichols, The Pope's Divisions (London: Penguin Books, 1981), p. 107. On the contrasting ideal of the church as "perfect society« see Patrick Granfield, »The Church as Societas Perfecta in the Schemata of Vatican I, « Church History 48 (1979), p. 431-46.

7 The Council of Basel (1439) in Godfrey Diekmann, Come, Let Us Worship (Baltimore: Jelicon Press 1968), p. 15. 
8 Dei verbum, section 9 (1965). For an overview of the evolution see K. McNamara, "From Möhler to Vatican II: The Modern Movement in Ecclesiology, « ed. K. McNamaras, Vatican II, the Constitution on the Church (Chicago: Franciscan Herald Press, 1968).

9 Yves Congar, »Johann Adam Möhler, "THQ 150 (1970) p. 47; see also Yves Congar, Tradition and Traditions: An Historical and Theological Essay (New York: Burns \& Oates, 1966).

${ }^{10}$ George H. Tavard, The Church, Community of Salvation: An Ecumenical Ecclesiology (Collegeville: The Liturgial Press 1992), p. 8.

1 E.L. Allen, Bishop Grundtvig: A Prophet of the North (London: James Clarke, 1944), p. 66. Among introductions to Grundtvig in English are Johannes Knudsen, Danish Rebel (Philadelphia: Muhlenberg Press, 1955), P.G. Lindhardt, Grundtvig: An Introduction (London: SPCK 1951), Hal Koch, Grundtvig, trans. Llewellyn Jones (Yelloq Springs: The Antioch Press 1952), and A.M. Allchin et. al. ed., N.F.S. Grundtvig: Heritage and Prophecy (Canterbury Press 1994).

12 Two weeks after Clausen's sizeable tome appeared, Grundtvig's forty-seven page pamphlet appeared in the bookshops of Copenhagen. The full title in English is The Church's Retort to Profesor of Theology Dr. H.N. Clausen.

13 In August 1825 Henrik N. Clausen had brought his volume Church-government, Dogma and Rite in Catholicism and Protestantism. Clausen, 17931877, had studied in Berlin under Schleiermacher, but also in Rome, and his book emphasized the common elements in all forms of Protestantism which are opposed to Catholicism: rationalism and the Bible as the two sources of right theology.

14 Toivo Harjunpas, »Grundtvig and his Incomparable Discovery, «The Lutheran Quarterly 25 (1973), p. 54-70.

15 Johannes Knudsen, »Revelation and Man According to N.F.S. Grundtvig," The Lutheran Quarterly 10 (1958), p. 217-55; Kaj Thaning, »Das Menschliche und das Christliche bei N.F.S. Grundtvig, « Kontroverse um Kierkegaard und Grundtvig (Berlin 1966), p. 58-80.

16 Henning Høirup, »Grundtvig and Kierkegaard: Their Views of the Church,«Theology Today 12 (1955), p. 330. 
17 Henning Høirup, "Grundtvigs Gedanken über Christentum und Volk, « Grundtvig Studier (1952), p. 72-81.

18 Allen, p. 75-76. On Grundtvig's Eucharistic theology see A.M. Allchin, «Grundtvig: An English Appreciation, «Worship 58 (1984), p. 420-33, and »Grundtvig's Catholicity,« N.F.S. Grundtvig (Copenhagen: The Danish Institute 1983), p. 11-21.

19 In a variety of ways Grundtvigianism in the Danish Church was a development paralleling the Oxford Movement in the Church of England and the Benedictine liturgical revival of Gueranger and the Abbey of Solesmes in France. On Pusey and Grundtvig see P.G. Lindhardt, „Grundtvig and England, « The Journal of Ecclesiastical History 1 (1950), p. 207-24; F. Aubrey Rush, »Letters from England: Grundtvig Writes Home,«The Norseman 11, p. 263-70. On Grundtvig and France see Erica Simon, »Grundtvig et la France,« Grundtvig Studier (1969), p. 7-22.

20 Friedrich Kalb, Theology of Worship in Seventeenth-century Lutheranism (St. Louis: Concordia 1965); A.M. Allchin, "The Hymns of N.F.S. Grundtvig,« The Eastern Churches Quarterly 13 (1959), p. 129-143.

Michael Grütering, Johann Adam Möhler und die Liturgie seiner Zeit (Ph.D. Dissertation: University of Bonn 1972).

22 On the »leftist « revival of the ideal of community in the nineteenth century see Robert Tucker, Philosophy and Myth in Karl Marx (Cambridge: Cambridge University Press 1967); Nikolaus Pevsner, Pioneers of Modern Design (London: Penguin Books 1974); David Watkin, Morality and Architecture (Oxford: Oxford University Press 1977); and on the »rightist « revival of the ideal of community see George L. Mosse, The Nationalization of the Masses (New York: Columbia University Press 1975); Fritz Stern, The Politics of Cultural Despair (Garden City: Doubleday and Co. 1965); and Barbara Miller Lane, Architecture and Politics in Germany (Cambridge: Harvard University Press 1968).

23 J.E.E.D. Action, Essays on Church and State (London: Hollis and Carter 1952). Möhler's reports from Berlin and the influence of Schleiermacher and Neander can be found in Stefan Lösch, Johann Adam Möhler: Gesammelte Aktenstücke und Briefe (Munich: Beck 1928), p. 89-90.

24 Thomas O'Meara, »'Christianity Is the Future of Paganism': Schelling's Philosophy of Religion, « in Meaning, Truth and God (Notre Dame: UND 1982), pp. $216 \mathrm{ff}$. 
On Schelling's impact on Möhler see Thomas O'Meara, Romantic Idealism and Roman Catholicism (Notre Dame: UND 1982).

Josef Rupert Geiselmann, Die theologische Anthropologie Johann Adam Möhlers: Ihr geschichtlicher Wandel (Freiburg 1955), p. 95.

Josef Rupert Geiselmann, Geist des Christentums und des Katholizismus. Ausgewählte Schriften Katholischer Theologie im Zeitalter des Deutschen Idealismus und der Romantik (Mainz 1940).

It is significant that Irenaeus devoted his writings in the second century to reconsiling the various sects which threatened to destroy the church by splitting it into fragments; his work which inspired Grundtvig, Against the Heresies, was the first systematic treatise on the concept of Catholic unity.

29 A book which places Romanticism as part of this longer evolution of Grundtvig's thought is Sven Bergrenz, N.F.S. Grundtvigs religiösa Idealism (Lund 1932).

Henrik Steffens, 1775-1845, was the son of Susanna Kristine, the younger sister of Grundtvig's mother. He was a fervent disciple of Schelling from his student days at Jena. He later became a professor at Halle and at Breslau, continued to follow Schelling, and was a leader in the German as well as the Danish Romantic movement.

31 C.I. Scharling, Grundtvig og Romantiken (Copenhagen: Gyldendal, Nordisk Forlag, 1947).

32 For an introduction in English on patristic influence see A.M. Allchin, »Grundtvig's Translations from the Greek, «The Eastern Churches Quarterly 16 (1961), p. 28-44.

33 For an introduction in English to these theological points in Grundtvig see A.M. Allchin, »Grundtvig: An English Appreciation, «Worship 58 (1984), p. 420-33, and »Grundtvig's Catholicity,« N.F.S. Grundtvig (Copenhagen: The Danish Institute 1983), p. 11-21.

34 Anton Mayer, "Liturgie, Romantik und Restauration, "Die Liturgie in der europäischen Geistesgeschichte (Darmstadt: Wissenschaftliche Buchgesellschaft 1971), p. 245. See by contrast the positive interpretation of the role of Romanticism in the more recent treatment, Thomas O'Meara, »The Origins of the Liturgical Movement and German Romanticism, « Worship 59 (1985), p. 326-342. 
Examples of the negative treatment of the impact of Romanticism on Christianity in Germany and Denmark may be found in Odo Casel, »Liturgiewissenschaft, « RGG (2nd ed.), 3, 1697 (Tübingen: Mohr 1929); Casel, »Liturgische Bewegung, «RGG (2nd ed.), 3, 1699; O. Rousseau, The Progress of the Liturgy (Westminster, Maryland: Newman 1951), pp. 51f; and an American study of Grundtvig, E.D. Nielsen, N.F.S. Grundtvig: An American Study (Rock Island: Augustana Book Concern 1955).

What is the proper understanding of the themes of international cooperation and ecumenism in Grundtvig? Grundtvig considered the cosmopolitan to be a form of unrealism. Of course Grundtvig was also unsympathetic to the Roman Church as it existed in his own time. The very concept of »Rome« became a sort of common term for everything he disliked in the church. In a long »Roman-Ballad« from 1837 Grundtvig enumerates all of Rome's sins. But nationalism in Grundtvig also leads us to frontiers where we meet others not as enemies but as fellow creatures. In Grundtvig's mind it was important for Denmark to seek right relations with the powers of Europe, above all England and Germany, in order to succeed.

Likewise, though Grundtvig was certainly non-Roman, there are points where Grundtvig's teaching converges with catholicism broadly understood. There is the catholicity of his teaching on the church, scripture, and the human which does not mean that it is Roman. On Grundtvig, Rome, and Catholicity see P. Schindler, Vejen til Rom (Copenhagen 1949) and E.D. Nielsen, "St. Thomas Aquinas on the Object of Faith, "The Augustana Quarterly XXVII (July 1948), p. 253-59; as well as P. Augustinus, »Grundtvig som vejviser til Rom«, Menighedsbladet XXXII (1950), pp. $132 \mathrm{ff}$.

Similarly, Möhler was critical of the simplistic ecumenism of the German Catholic liberals of Württemberg who naively imagined a rapid progress toward church unity in the nineteenth century. But Möhler did believe that a new theology of the church, written in the spirit of the times, would be a point of contact for the future. He predicted in the Symbolik »that this is the point at which Catholics and Protestants will, in great multitudes, one day meet, and stretch a friendly hand one to the other. Both, conscious of guilt, must exclaim, 'We all have erred - it is the Church only which cannot err; we all have sinned - the Church only is spotless on earth.' " Symbolik, p. 349. 